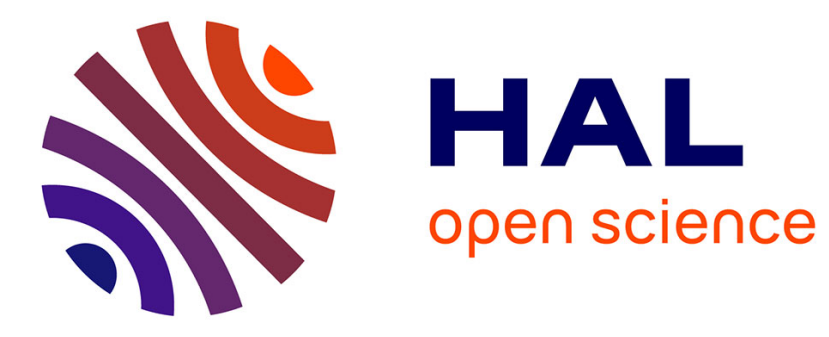

\title{
Monitoring the decrease of Lake Chad from space
}

Lucien Wald

\section{To cite this version:}

Lucien Wald. Monitoring the decrease of Lake Chad from space. Geocarto International, 1990, 5 (3), pp.31-36. hal-00464061

\section{HAL Id: hal-00464061 \\ https://hal-mines-paristech.archives-ouvertes.fr/hal-00464061}

Submitted on 14 Apr 2010

HAL is a multi-disciplinary open access archive for the deposit and dissemination of scientific research documents, whether they are published or not. The documents may come from teaching and research institutions in France or abroad, or from public or private research centers.
L'archive ouverte pluridisciplinaire HAL, est destinée au dépôt et à la diffusion de documents scientifiques de niveau recherche, publiés ou non, émanant des établissements d'enseignement et de recherche français ou étrangers, des laboratoires publics ou privés. 


\title{
Monitoring the Decrease of Lake Chad from Space
}

\author{
Lucien Wald \\ Centre de Télédétection et d'Analyse des Milieux Naturels (CTAMN) \\ Ecole Nationale Supérieure des Mines de Paris \\ Rue Claude Daunesse \\ Sophia-Antipolis, 06565 Valbonne Cédex \\ France
}

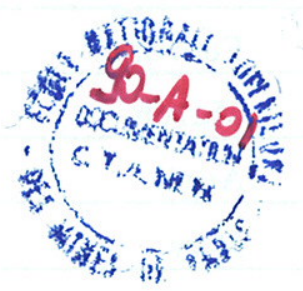

\begin{abstract}
Observations from space of the open water areas within Lake Chad are presented. They complement and sustain the earlier study of Mohler et al. (1989), which demonstrates a decrease of about 90 percent in surface between 1966 and 1986. Further, Meteosat images were processed to obtain weekly maps of albedo following the scheme of Mousssu et al. (1989). The analysis of these maps throughout the year reveals the functioning of the lake as well as the large variability of the open water areas during a year.
\end{abstract}

\section{Introduction}

Lake Chad is a large, closed catchment basin located in the western Sahel (Figure 1), and.is part of the borders of the four countries of Cameroon, Chad, Niger and Nigeria. As a closed hydrologic system, fluctuations of Lake Chad serve as an excellent climatic indicator of prolonged drought which has affected the western Sahel since the late 1960's, the third major drought of the region this century (Leroux, 1983; Glantz, 1987). Since 1968, the lake has contracted to less than one-tenth of its maximum 1963 surface area of 23,000 sq km (Grove, 1978).

Lake Chad is intensively studied using remote sensing data from the geostationary satellite Meteosat (Anonymous, 1989; Citeau et al., 1989; Diabaté et al., 1989) and the polar orbiting NOAA satellites (Mohler, Amsbury, 1989; Rigal, 1989). As one of the most prominent features in Africa, it is also often photographied by space crex/s (Wood, Helfert, 1985; Greer, 1989; Helfert, Lulla, 1989; Lulla, Helfert, 1989). Recently, Mohler et al. (1989) published estimates of open water areas in Lake Chad from 1966 to 1986 and showed a decrease of 93 percent in surface during that period. The present note intends to complement their investigations by taking into account some observations published in journals of limited diffusion as well as observations made at Ecole des Mines de Paris.

\section{Data and Their Processing}

According to Leroux (1983), the climate over Lake Chad is dry, weakly rainy and warm. It offers two seasons: the harmattan season from October to April, and the atlantic monsoon from May to September. Despite the fairly small north-south extension of $210 \mathrm{~km}$ of the lake, the climate varies from south to north, the seasons beginning and ending one month later in the north than in the south Mean annual temperature is about $28^{\circ}$ Celsius, with a mean annual variation of about $10^{\circ}$ Celsius. Mean annual humidity is close to $30 \%$ with a ratio between extreme monthly averages equal to 4 . The mean annual total of rainfall amounts to $250 \mathrm{~mm}$ in the north and to $500 \mathrm{~mm}$ in the south. The seasonal variation is large, with no precipitation during the harmattan season and a peak in August (see Table 1). Of interest are also the precipitations in the south of the lake, over the drainage basin of the Logone and Chari rivers (Table 1). These rivers feed Lake Chad, and contribute, together with their drainage river El Beid, to about $99 \%$ of the annual inflow (Kolawole, 1987; Bardinet, Monget, 1980). To conclude this paragraph, it must be stressed that the interannual variability of this area is very large. The atlantic monsoon season can be late or early, stops early or lasts in late fall. Dry periods can also occur during this season, and the amount of rainfall is highly variable.

\section{Observations from Space and Their Processing}

In order to study the decrease of the Lake Chad between $196^{\circ} 6$ and 1986, Mohler et al. (1989) selected eight photographs taken by the crews during Gemini, Skylab and Space Shuttle missions. After digitization, the images were registered to a previously digitized map compiled by the 


\begin{tabular}{|l|c|c|c|}
\hline Month & North & South & Logone and Chari Basin \\
\hline January & $<1$ & $<1$ & 2 \\
\hline February & $<1$ & $<1$ & 2 \\
\hline March & $<1$ & $<1$ & $5-10$ \\
\hline April & $<1$ & 2 & $30-40$ \\
\hline May & 5 & 20 & $50-75$ \\
\hline June & 10 & 40 & $125-200$ \\
\hline July & 50 & 100 & 300 \\
\hline August & 125 & 250 & $100-150$ \\
\hline September & 10 & 50 & $20-50$ \\
\hline October & 3 & 10 & $1-2$ \\
\hline November & $<1$ & $<1$ & $<1$ \\
\hline December & $<1$ & $<1$ & $\mathbf{5 0 0 - 1 0 0 0}$ \\
\hline \hline TOTAL & 250 & $\mathbf{5 0 0}$ & 2 \\
\hline
\end{tabular}

Table 1. Mean monthly rainfall over Lake Chad and the drainage basin of Logone and Chari rivers (in mm). After Leroux (1983).

United States Defense Mapping Agency Topographic Center, and classified as either land or water. The open water area is then estimated for each image.

To complement their work, I add 'to their findings the estimate made by Wood et al. (1989) from another Space Shuttle image. I also use either Meteosat images processed at Ecole des Mines de Paris, or some maps derived from satellite data found in articles written in journals of restricted diffusion. From these maps, I compute the open water area when possible, either by using the scale when given, or by comparison to the sizes of Lake Chad itself (see Fig. 1). These articles are the followings.

Mohler and Amsbury (1989) present an AVHRR image which has been processed using both the Normalized Difference Vegetation Index (NDVI) and a kind of classification method, called Comprehensive Analysis for Unitemporal Scene Evaluation. Two large colour pictures allow the mapping of the open water area for April 15, 1985. Rigal (1989) uses two different indexes to classify the objects within AVHRR images of Lake Chad. One is the NDVI and the other, a similar index but constructed from thermal infra-red (channel 5) and near infrared (channel 2). The different behaviours of both indexes permit him to map the open water for late fall 1988 and winter 1989. Citeau et al. (1989) map the open water areas for November 1988 using a colour composite of the visible and thermal infrared channels of the Meteosat imagery. Anonymous (1989) shows two maps derived from Meteosat images, November 1988 and April 1989. Processing made at the
National Remote Sensing Center, Farnborough, United Kingdom, involves radiometric balancing of image extracts from different dates to compensate for seasonal differences in local solar elevation, followed by density slicing to highlight differences in digital values.

As already said, I make an extensive use of Meteosat

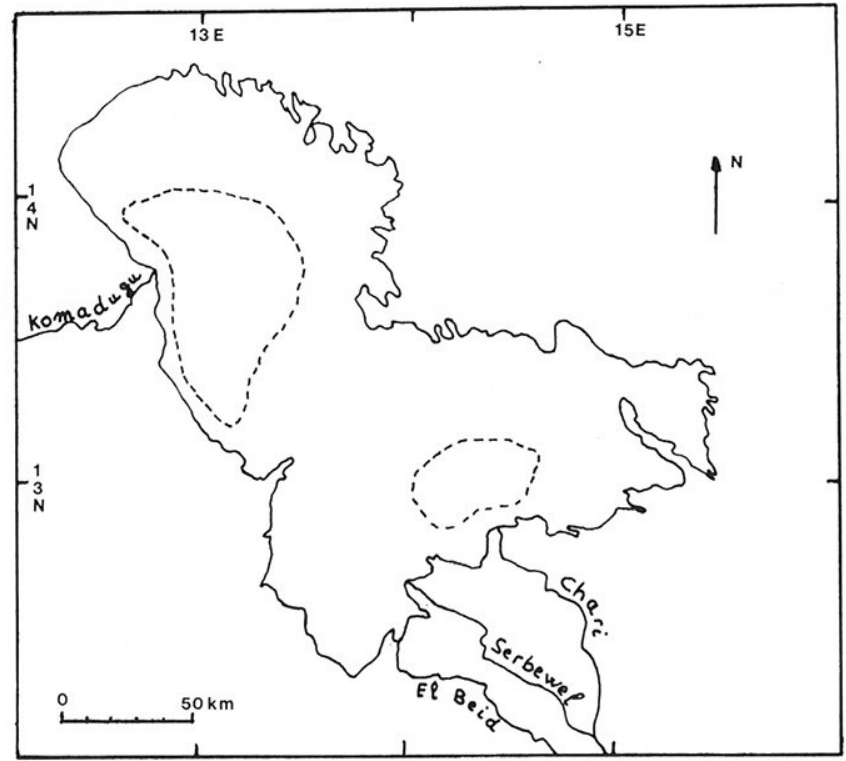

Figure 1 Map of Lake Chad at the beginning of July 1973 The areas surrounded by broken lines denote open water and cover 4,190 sq km. After Chourct ct al. (1977). 
imagery. The Meteosat data originate from the archives of the European Space Agency, or from a direct reception in 1984 using a Secondary Data User Station (SDUS) connected to a personal computer as described by Diabaté et al. (1989a) or Wald et al. (1990). These images have been processed using the Minimage software library of Ecole des Mines de Paris, according to the scheme proposed by Moussu et al. (1989) to obtain weekly maps of the ground albedo. Such a methodology has been successfully applied by Diabaté et al. (1989b) to Meteosat imagery, to depict the variations both in space and time of the vegetation in Sahel. When applied to Lake Chad, these maps of ground albedo also indicate the open water areas which exhibit low albedo. The albedo increases as the water thickness decreases. Apart the deep water, the lower values characterize the areas composed of water and reed while clay soils show up higher albedos with a dependence upon the soil moisture content and the vegetation coverage. For each weekly map of albedo, the pixels were classified as either open water or not, using a threshold technique applied to the whole image covering part of Sahel as well as parts of the Atlantic Ocean. The threshold was set as being the upper limit of the range of values which characterize the ocean. A small superior margin was allowed to take into account that due to the broad spectral band of Meteosat visible channel $(0.4-1.1 \mu \mathrm{m})$ an increase of the chlorophyll content of the water increases the albedo, because of the response of the green vegetation in near infrared spectral band. According to the relationship between the digital counts of such maps and the actual albedo given by Moussu et al. (1989), the albedo of the open water pixels ranges between 0.0 to 0.05 . Once the pixels classified, the open water pixels within Lake Chad were counted (Fig. 2). Accuracy in areal estimates has been evaluated to about $20 \%$.

\section{Results}

The area estimates made during this study are listed in Table 2, together with the results of Mohler et al.. My estimates are in agreement with those of Mohler et al. when dates coincide, within the limits of accuracy. Open water areas range from a high of 22,772 sq km during the Gemini mission in June 1966 when Lake Chad was near its historical maximum, to a low of $500 \mathrm{sq} \mathrm{km}$ in April 1989. From 1966 to nowadays, Lake Chad had contracted by a factor of about twelve. This is the direct consequence of the prolonged drought affecting Sahel since the late 1960's. Less rain falls on the Logone - Chari basin and Lake Chad itself and therefore the volume of water in the lake is lower than three decades earlier. However, for the last fifteen years, open water areas are quite stable, and no negative trend can be observed furthermore. The areas covered by open water are very often greater in the southern basin than in the northern one, but the reverse occurs from time to time.

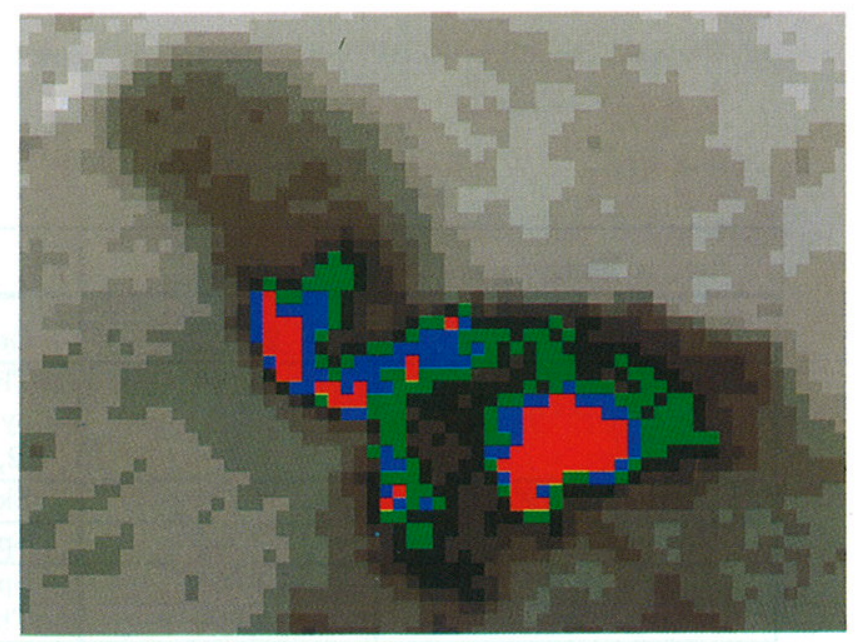

Figure 2 This map of albedo has been obtained from the processing of Meteosat images of December 1985, week 49. Albedo increases from red, blue, green, violin, black to white. Only red pixels are labelled open water and total area amounts to $2,000 \mathrm{sq} \mathrm{km}$. Albedo for red pixels ranges from 0 to 0.05 , from 0,05 to 0.07 for blue, 0.07 to 0.09 for green. A change in grey level means a change of 0.02 in albedo.

High variability in open water areas can be observed for a same month from year to year. In Table 3 are computed for each month the average values of the observations available for this month. Of course, data from June 1966 have not been taken into account. The standard deviations are often of small interest because of the low number of observations. This table indicates that the open water areas do vary from year to year and this is in agreement with the variability of the rain falling on Lake Chad itself and on the Logone - Chari basin.

Table 4 illustrates the variability of the open water areas throughout the year 1984. Although in the dry season, January presents a high of $3,000 \mathrm{sq} \mathrm{km}$ which is a consequence of the rainfall of the year 1983 as explained later. The dry season goes on and the dessication of the lake increases until May where the open water area reaches a low of $1,000 \mathrm{sq} \mathrm{km}$. Rain begins to fall in June, so that the area is maintained at this low. The increase in rain leads to an increase in open water in summer. The level of water increases more in the southern basin than in the northern one because there is more rain in the south. In October, the rain comes to a halt, and the decrease in the water level indicates that evaporation efficiently begins particularly in the north. Late November the southern basin is fed by the flood of the Logone - Chari - El Beid rivers system. This important but slow supply makes the water level increase to reach a maximum in January.

The observations are well sustained by the works of Rigal and others (see Table 2), who found a low level of water at the beginning of November 1988, following a higher level in October. This level increases with occurrence of the flood and reaches a maximum in winter 1989 


\begin{tabular}{|c|c|c|}
\hline Date & Area & Origin of document and of estimates \\
\hline June 1966 & 22,772 & Gemini mission. In Mohler et al. (1989) \\
\hline July 1973 & 4,190 & $\begin{array}{l}\text { This study. After a ground measurements-based map } \\
\text { by Chouret et al. (1977). } \\
\text { ( } 2,330 \text { north and } 1,860 \text { south). }\end{array}$ \\
\hline September 1973 & 1,752 & Skylab. In Mohler et al. \\
\hline November 1982 & 2,276 & Space Shuttle. In Mohler et al. \\
\hline August 1984 & $\begin{array}{l}1,655 \\
2,000\end{array}$ & $\begin{array}{l}\text { Space Shuttle. In Mohler et al. } \\
\text { This study (see Table 4) }\end{array}$ \\
\hline October 1984 & $\begin{array}{l}1,678 \\
2,050\end{array}$ & $\begin{array}{l}\text { Space Shuttle. In Mohler et al. } \\
\text { This study (see Table 4) }\end{array}$ \\
\hline November 1984 & $\begin{array}{l}1,689 \\
1,300\end{array}$ & $\begin{array}{l}\text { Space Shuttle. In Mohler et al. } \\
\text { This study (see Table 4) }\end{array}$ \\
\hline April 1985 & 1,653 & Space Shuttle. In Mohler et al. \\
\hline 15 April 1985 & 1,200 & $\begin{array}{l}\text { This study, after Mohler, Amsbury (1989) } \\
\text { (1,200 south). }\end{array}$ \\
\hline June 85 (Week 22) & 1,500 & $\begin{array}{l}\text { This study. From processing of Meteosat imagery } \\
(1,500 \text { south })\end{array}$ \\
\hline Dec. 85 (Week 49) & 2,000 & $\begin{array}{l}\text { This study. From processing of Meteosat imagery } \\
\text { (600 north and } 1,400 \text { south) }\end{array}$ \\
\hline January 1986 & 4,452 & Space Shuttle. In Mohler et al. \\
\hline June 86 (Week 22) & 1,200 & $\begin{array}{l}\text { This study. From processing of Meteosat imagery } \\
(1,200 \text { south) }\end{array}$ \\
\hline Dec. 86 (Week 49) & 2,300 & $\begin{array}{l}\text { This study. From processing of Meteosat imagery } \\
\text { ( } 700 \text { north and } 1,600 \text { south) }\end{array}$ \\
\hline 1 October 1988 & 1,300 & Space Shuttle. In Wood et al. (1989) \\
\hline November 1988 & 1,490 & $\begin{array}{l}\text { This study. After Anonymous (1989) } \\
\text { ( } 880 \text { north and } 610 \text { south) }\end{array}$ \\
\hline 3 November 1988 & 1,100 & $\begin{array}{l}\text { This study. After Rigal (1989) } \\
(290 \text { north and } 830 \text { south) }\end{array}$ \\
\hline 11 November 1988 & 1,200 & $\begin{array}{l}\text { This study. After Citeau et al. (1989) } \\
\text { ( } 450 \text { north and } 750 \text { south) }\end{array}$ \\
\hline 24 November 1988 & 1,800 & $\begin{array}{l}\text { This study. After Rigal (1989) } \\
\text { ( } 640 \text { north and } 1,200 \text { south) }\end{array}$ \\
\hline 14 February 1989 & 3,140 & $\begin{array}{l}\text { This study. After Rigal (1989) } \\
\text { (1,940 north and } 1,200 \text { south) }\end{array}$ \\
\hline 14 March 1989 & 1,200 & $\begin{array}{l}\text { This study. After Rigal (1989) } \\
\text { ( } 380 \text { north and } 840 \text { south) }\end{array}$ \\
\hline 11 April 1989 & 500 & $\begin{array}{l}\text { This study. After Rigal (1989) } \\
\text { (500 south) }\end{array}$ \\
\hline April 1989 & 980 & $\begin{array}{l}\text { This study. After Anonymous (1989) } \\
\text { (440 north and } 560 \text { south) }\end{array}$ \\
\hline
\end{tabular}

Table 2. Estimates of open water area for Lake Chad according to various observations from space (in sq km). 


\begin{tabular}{|l|c|c|c|c|c|}
\hline \multicolumn{1}{|c|}{ Month } & $\begin{array}{c}\text { Number of } \\
\text { observations }\end{array}$ & $\begin{array}{c}\text { Mean area } \\
(\mathbf{s q ~ k m})\end{array}$ & $\begin{array}{c}\text { Standard } \\
(\mathbf{s q ~ k m})\end{array}$ & $\begin{array}{c}\text { Minimum } \\
\text { area (sq km) }\end{array}$ & $\begin{array}{c}\text { Maximum } \\
\text { area (sq km) }\end{array}$ \\
\hline \hline January & 2 & 3,726 & - & 3,000 & 4,452 \\
\hline February & 2 & 2,820 & - & 2,500 & 3,140 \\
\hline March & 2 & 1,250 & - & 1,200 & 1,300 \\
\hline April & 5 & 1,127 & 381 & 500 & 1,653 \\
\hline May & 1 & 1,000 & - & 1,000 & 1,000 \\
\hline June & 2 & 1,350 & - & 1,200 & 1,500 \\
\hline July & 2 & 2,995 & - & 1,800 & 4,190 \\
\hline August & 2 & 1,828 & - & 1,655 & 2,000 \\
\hline September & 2 & 1,976 & - & 1,752 & 2,200 \\
\hline October & 3 & 1,676 & - & 1,300 & 2,050 \\
\hline November & 7 & 1,551 & 378 & 1,100 & 2,276 \\
\hline December & 3 & 1,900 & - & 1,400 & 2,300 \\
\hline \hline All data merged & $\mathbf{3 5}$ & $\mathbf{1 , 8 0 4}$ & $\mathbf{8 3 4}$ & $\mathbf{5 0 0}$ & $\mathbf{4 , 4 5 2}$ \\
\hline
\end{tabular}

Table 3. Annual variability of the open water areas. Data from June 1966 have not been taken into account.

\begin{tabular}{|l|c|c|c|}
\hline Month and Week & Total area & Southern basin & Northern basin \\
\hline January, week 4 & 3,000 & 2,100 & 900 \\
\hline February, week 6 & 2,500 & 1,800 & 700 \\
\hline March, week 10 & 1,300 & 1,300 & - \\
\hline April, week 15 & 1,300 & 1,300 & - \\
\hline May & 1,000 & 1,000 & - \\
\hline June & 1,000 & 1,000 & 500 \\
\hline July, week 27 & 1,800 & 1,300 & 500 \\
\hline August & 2,000 & 1,500 & 500 \\
\hline September & 2,200 & 1,700 & 400 \\
\hline October, week 42 & 2,200 & 1,800 & 300 \\
\hline October, week 43 & 1,900 & 1,600 & - \\
\hline November, week 45 & 1,200 & 1,200 & - \\
\hline November, week 47 & 1,400 & 1,400 & - \\
\hline December & 1,400 & 1,400 & - \\
\hline
\end{tabular}

Table 4. Estimates of open water area for Lake Chad using Meteosat imagery in 1984 (in sq km). 
to decrease sharply in April 1989. Also relevant are my observations of early December 1985 (2,000 sq km) preceding the observations of Mohler et al. in January 1986 $(4,452 \mathrm{sq} \mathrm{km})$. Table 3 supports these conclusions but reciprocally, they cannot be drawn out from this statistical table because of the low confidence level of its content due to the very weak number of observation.

\section{Conclusion}

During the great drought of 1968 to 1974 , the water level within Lake Chad fell considerably by about $90 \%$. Since then the lake has not recovered its ancient maximum. For the last few decades, the open water areas amount to an average of about 1,800 sq km, and do not show any sign of further decline.

The seasonal as well as yearly variabilities of the water level are very high, and coincide with those of the rainfalls in this geographical region. During the year, the water level presents two highs and two lows. The first low occurs at the end of the dry season: March - April, and is the absolute minimum observed in the year. Then, the rain falls onto the lake making the water level rises up to a high reached in summer. Once the rain stops, the water level slowly decreases down to a low in November. Then, the Logone - Chari - El Beid rivers system floods in the lake slowly and makes the level rise up to the yearly maximum in January.

Images from space do not reveal the whole recent history of Lake Chad. But they make it possible to monitor daily this particular area. Provided some calibrations of satellite-derived informations are done with relevant ground measurements, the impact of such a monitoring of the local economics is largely evident.

\section{References}

Anonymous, 1989, Meteosat for flood monitoring. Earth Observation Quaterly, 26, 4-5.

Bardinet, C., and Monget, J.M., 1980, Lanchad: Télédetection et géographie appliquée en zone sahélienne du Tchad. Collection de l'Ecole Normale Supérieure de Jeunes Filles, Paris, France, Vol. 12, $544 \mathrm{pp}$.

Chouret, A., Fontes, I.C., and Mathieu, P., 1977, La nappe phréatique à la périphérie du Lac Tchad. Etude de l'Office de Recherche Scientifique et Technique Outre-Mer, Paris, France.
Citeau, J., Demarcq, H., Mahé, G., and Franc, J., 1989, Une nouvelle station est née. Veille Climatique Satellitaire, 25, 23-29.

Diabaté, L., Moussu, G., and Wald, L., 1989 (a), Description of an operational tool for determining global solar radiation at ground using geostationary satellite images. Solar Energy, 42 (3), 201-207.

Diabaté, L., Michaud-Regas, N., and Wald, L., 1989 (b), Mapping the ground albedo of western Africa and its time evolution during 1984 using Meteosat visible data. Remote Sensing of Environment, 27 (3), 211-222.

Glantz, M.H., 1987, Drought in Africa. Scientific American, 256(6), 34-40.

Greer, J.D., 1989, Space Shuttle large format camera coverage of areas in Africa: a review of the mission and the photographs acquired. Geocarto International, 2, 19-33.

Grove, A.T., 1978, Geographical introduction to the Sahel Geographical Journal, 144(3), 407-415.

Helfert, M.R., and Lulla, K.P., 1989, Monitoring tropical environments with Space Shuttle photography. Geocarto International, 1, 55-67.

Kolawole, A., 1987, Environmental change and the South Chad irrigation Project (Nigeria). Journal of Arid Environments, 13. $169-176$

Leroux, M., 1983, Le climat de l'Afrique Tropicale, Editions Champion, Paris, Vol. 1, 633 pp. and Vol. 2, 250 maps.

Lulla, K.P., and Helfert, M.R., 1989, Space Shuttle Earth Observations. Geocarto International, 2, 49-53

Mohler, R.R., and Amsbury, D.L., 1988, Extension of a drought monitoring and vegetation classification methodology to the western Sahel. Geocarto International, 4,29-36.

Mohler, R.R., Helfert, M.R., and Giardino, J.R., 1989, THe decrease of Lake Chad as documented during twenty years of manned space flight. Geocarto International, 1, 75-79

Moussu, G., Diabaté, L., Obrecht, D., and Wald, L., 1989. A method for the mapping of the apparent ground brightness using geostationary satellite images. International Journal of Remote Sensing, 10(7), 1207-1225.

Rigal, D., 1989, Crue et décrue au Lac Tchad. Veille Climatique Satellitaire, 28. 71-76.

Wald, L., Wald, J.L., and Moussu, G., 1990, A low-cost high-quality system for the acquisition and digital processing of Meteosat GOES/GMS images of WEFAX type. Submitted to International Journal of Remote Sensing.

Wood, C.A., and Helfert, M.R., 1985, Shuttle crews record shrinking Lake Chad. Geotimes, 30(12), 4.

Wood, C.A., Helfert, M.R., and Lulla, K.P., 1989, Earth observations during Space Shuttle flight: STS-26. Discovery's mission to Earth. September 29 - October 3, 1988. Geocarto International, 2, 55-63. 